\title{
WEBER'S HISTORICISM AS A WAY INTO PHENOMENOLOGY
}

\section{Fabricio Pontin}

Pontifícia Universidade Católica do Rio Grande do Sul (PUCRS), Porto Alegre - RS, Brasil. E-mail: fpontin@gmail.com

\section{Tatiana Vargas Maia}

Centro Universitário La Salle (UniLasalle), Canoas - RS, Brasil. E-mail: vargasmaia@gmail.com

DOI: $10.17666 / 329511 / 2017$

\section{Introduction}

This article is an attempt to give an account of the problem of historicity in Weber. At first, we highlight the origins of his understanding of identity and identity formation in modern philosophy, more specifically, in Hobbes. As we will see, assuming that Hobbes provided us with an account for the individual in the transition between feudalism and capitalism, Weber provides us with a sociology that describes the stages of socio-individual relations in a consolidated capitalist society. These stages do not aim at a hypothetical description, but at how individuals are actually deciding on values and actions (and, eventually, ideals). In our first section, we try to point out that Weber's account of history is deeply indebted to the Hobbes own

Artigo recebido em 12/07/2016

Aprovado em 24/05/2017 account of the emergence of normative, meaninglike, action orientation only within the political. First of all, we will try to demonstrate that Hobbes seems to be validated by Weber in some of his insights about identity formation and society. In this sense, understanding the description of the society in Hobbes will allow us to comprehend the historical constitution of identity, particularly, what constitutes the rational orientation of a first person perspective in Weber. In short, it seems to us that at the roots of the Weberian insights about social action and choice, there is a deeply Hobbesian inspiration in that individuals are able to conceive of preferences and values in a unique sense. Therefore, there is something about the way in which we conceive of our own values that is peculiar only to ourselves, as individuals.

Further, we move away from Hobbes, stressing the importance of the social to the formation of the state in Weber, pointing at a phenomenological 
deficit in his social theory, which remains restricted to an analysis of how individuals are able to represent their own experiences into concepts, and how these concepts will shape the normative ethos of modern societies. We suggest that Weber's restrict understanding of personal and group identity in representational terms is too narrow for our ambivalent, and sometimes anarchic, acknowledgment of reality. Though, curiously, such acknowledgment of an anarchic, prerepresentational, ground of individual and social constitution seems to presuppose the very methodological standpoint that Weber had introduced.

Weber's understanding of the process of selfconstitution is somewhat monadic. Considering his discussions on the tripartite constitution of meaning, we will perceive that there is a first level of constitution of meaning, in which an individual is in interaction only with external objects - and not with others. Weber divides the relationship of meaning and action as a progression. When an individual is immersed in social relations, his/her first considerations about beliefs are first expressed in terms of "social action". In Weber, such kind of action, means to say something, i.e., it is an action that is oriented to affirm a kind of belief " $q$ ". These beliefs " $\mathrm{q}$ " were first constituted in a radically individual context, then, Weber considers this an "observational understanding", in which individuals intend meaning at the world. However, meaning is further developed: surely, a first level is only observational and has not immediate relation with others, but as socialization is complexified, meaning is interpreted in terms of "motivational" understanding. Social interaction, then, is a tension between different personal comprehensions of the structure of the world "out there", and different historicizations and idealizations.

As we will see, Weber's historical perspectivism presupposes that personal and group identity, and individual and social action are connected to a stock of representations. That is, they are connected to a meaning-like constitution of individual and personal mores, which is to say, to individuals that act in society, according to a pre-established meaning-complex set of preferences that are historically constituted in a relation between the individual and the social.
There is no underestimate about the impact that such notion of historicity has on social thought. Weber's account of identity and society remains a paradigmatic necessity and shapes our understanding of how individuals get to have preferences and form a sense of self in modern societies. However, for all its paradigmatic importance, Weber's account of the formation of self and identity has a blind spot in the notion of representation.

In our understanding the centrality of the notion of representation for the Weber's understanding of social action and selfhood leaves him in a nominalistic position, in which action must reproduce normatively established "types" in order to be meaningful, i.e., in Weber, the same as saying that social action must be rational in order to be social. Thus, though knowledge is produced locally, social life aims at and is limited by the production of knowledge. Our conclusion attempts to demonstrate that such focus on knowledge and representation leaves Weber unable to deal with the problem of disorder in social life without resorting to an interpretation of disorder as irrationality, which, we hold, is no longer acceptable.

\section{The monist origins of social epistemology}

In Hobbes, we will see the transition between classical forms of political theory towards a more modern understanding of politics, something similar to liberalism. This is because Hobbes will contest the Aristotelian doctrine of language as a natural potency that was realized by men in reason and will define it as an invention. This is not to say language - or speech, for that matter - is not important for Hobbes. The importance of speech, as a matter of fact, is described in quite hyperbolic phrasing. ${ }^{1}$

Initially, we can identify a sharp difference between Hobbes and Aristotle, and this difference is one that is going to shape modernity and its opposition to the political model of Ancient and Medieval philosophy. Considering that in Aristotle, language and speech are natural properties of men that are discovered and realized in political praxis, in Hobbes, speech is invented as a tool for com- 
munication (Berlin, 1984, p. 21). The experience of sense, in Hobbes, is first private (Hobbes, 2005 , p. 553). It is a relation of forces where the external body in relation to the external world starts a chain of causes that is finally identified as the sensing of something in the external world (Idem, pp. 554-555). This experience does not require others; it does not require difference or even language capable of describing such experience of sense. It is an unpolluted first person perspective. Such pure sensation turns to be more complex as we imagine and represent sensible characteristics of the external world. Again, this process of imagination is prior to the appearance of speech ${ }^{2}$ - but the train of thoughts or consequences of imagination requires something Hobbes calls mental discourse (Idem, p. 557). This kind of discourse is still purely internal, but it is already linguistic in the sense that there is a reproducible function of a determined sense, a remembering of one's action. However, the communication of a sense requires an externalization of internal discourse, and this externalization is speech. Weber will later define this first "stage" of the meaning constitution as observational understanding (Weber, 1956, pp. 8-12).

In opposition to Aristotle, wherein the sensing of the world required the social construction and placement of men (Aristotle, 1998), in Hobbes the sensing of the world does not yet require the insertion in a place wherein one can speak. Prior to the constitution of the political space (the commonwealth) by men, we already have an internal representation of sense - in Aristotle, prior to this constitution all we have is had in a silent form, it is had in a state of no-conation, of a sense without representation. However, why is this relevant?

It is relevant because we are dealing, in Hobbes, with two colliding notions of discourse and language. On the one hand, we have private experiences of sense that are represented internally, on the other, we have the public assertion of these representations where we index and communicate our thoughts to others. Hobbes is shaping a distinction between private and public reason, expressed as a tension between marking and signifying, wherein marking is a private action of indexation and labeling, and signifying is a dem- onstration of what is meant by a determined mark. It is a demonstration of a sign (Hobbes, 2005, p. 559). He is also pointing at the emergence of the isolated individual. Hobbesian metaphysics is in effect responding to the rise of individualism as a political phenomenon (Rawls, 2007, p. 34). The disastrous politics that led to the English Civil War of 1642 might have been the main motivation for the writing of the Leviathan, and it certainly plays a role in Hobbes understanding of the motivation of individuals under the absence of a strong social contract and government.

There should be no surprise, then, when the issue of the sign is problematized politically, in the relation between two individuals that assert different marks to each other. When discourse becomes speech, politics is born. Since men have equal faculties and potentialities (Hobbes, 2005, p. 591), they strive to impose their respective private assertions as the dominant ones. This competition to awe the others and to obliterate the different conceptions of "marks", and attempts to signify the external world shapes the commonwealth.

If we follow Hobbes, the problem of communication arises as a question of morality. When expressing sense, one is communicating a form of value. If one says, "the field is green" or "killing is wrong", the adjective value that is expressed is one the speaker will be willing to sustain especially if the other speaker is saying, "the field is blue" or "killing is sometimes acceptable." For Hobbes, as long as the individuals are in a position of equality and no dimension of sense is made public, war will prevail. This is because men need a determined form of indexation to be the form of signification, which is common to all men. Hobbes does not entirely dispute the classical notion of language as convention, such as the one that we find in Aristotle. However, if in Aristotle the use of reason could lead to an irresistible grammatical structure of norms and speech, for Hobbes no convention of this sort is possible without a dominant power that imposes a way of speaking and a standard of indexation. Such sovereign imposition is, nota bene, one of content, not of form. This means that what the forthcoming social contract regulates is not simply the form of an expression; it is the content of an indexation, 
which is limited by the contract. In this, Hobbes is still a son of feudal organization (Gay, 1966, p. 17). A higher form of order, preferably Divine, is preferable for social organization, rather than hoping for a consensual ordering of desires by individuals. The paradigmatic shift in Hobbes is clear, though, when we realize that singular opinions may still be relevant privately, and are not dependent on divine inspiration. Still, the dominant form has a determined content and scope - and that is the scope any publicly held expression must follow.

But for all his demands for a strong hand dealing the cards of what is and what is not feasible in the social order, Hobbes requires some sort of representation in the contract. In this sense, singular opinions must find some support on the contract; otherwise, individuals will not be prone to transfer their singularity to the State. Consequently, the State seeks to reduce difference in opinion and action through the contract, and in the Leviathan the rights of the individual person are connected to the renounce of individual wills to the will-ofthe-State. The discursive practices are then limited politically in order to tame the inclination to conflict of individuals in the anarchic position - and power is limited to the scope of the contract. Thus, the sphere of thought, of private life and internal practices are not regulated - and could not be regulated - by contract. It is interesting to note that the emergence of rights of privacy and to private life is only possible when the individual is situated under the rule of the sovereign. Before the emergence of the written law and the contract, individuals do not have any rights of personality. They are neither people nor subjects, but merely living bodies that are not situated in proper political relation, but in anarchic conflict.

Egotistic individuals will only recognize each other, in Hobbes, as this other is inserted in a space of similitude: into a political space and as a political body - as persons. This movement is both discursive and exclusionary. It also grounds a new form of understanding politics: as an artificial construction of a space for discourse and action. This separation of the individual in the State as a relevant and protected being and the individual outside the state as an abandoned and anarchic singularity that neither respects nor needs protection would shape modernity - and define liberalism as a theoretical school of thought. It also paves the way for the understanding of the Empire of Rights as characteristic of the modern age.

\section{Towards social action}

If Hobbes provided us with an account for the individual in the transition between feudalism and capitalism, Weber provides us with a sociology that describes the stages of socio-individual relations in a consolidated capitalist society. These stages do not aim at a hypothetical description, but at how individuals are actually deciding on values and actions (and, eventually, ideals).

The main insight in Weberian sociology, in which the questions of meaning and action are integrated into social relations, points at current discussions that continue to dominate the debate in political theory. Weber's influence and his importance are not limited to a consideration of his reach in political theory. The practical reach of Weberian sociology reshaped politics in Europe, for example, the idea of historicization mandates the abandonment of any idea of "superior" or "original" understanding of a people. Rather, Weber shows that ideals held as superior and original are historical constructions; idealizations inserted in a social context. Nevertheless, he also points out the universal character of such processes. Thus, even if there are multiple understandings of identity, and of types, these understandings are dependent on an external reality, and the shifts in the understanding of external phenomena is not expressive of a different capability of thinking, but rather of a different set of circumstances that call for a different form of constitution.

\section{Meaning and identity constitution}

Weber starts his description of social action with an account of how individuals will develop their own conceptualizations about the external world (Weber, 1956, p. 4). For Weber, this process is fundamentally solitary: an individual might be 
immersed in social and institutional life from the moment of his/her conception, but his/her appropriation of meaning is, at least in a first moment, a first person perspective of external reality.

Individuals will incorporate the materiality of external reality as their own social reality, but remember that the social reality, at this stage, is reduced as the way in which an isolated subject incorporates objects into his/her mind. ${ }^{3}$ This creates a network of references, where objects become identical to their appropriation in the mind of the individual - such reference process trusts a singular lexicon for individual conceptualizations about the world "out there". ${ }^{4}$

In this sense, there is an observational understanding of reality, which creates an individual appropriation of social reality - a sort of social reality "for me". Therefore, an object " $\mathrm{x}$ " is the object " $\mathrm{x}$ " as I have constituted and labeled it " $x$ ". This is the first emergence of what Weber names a "type" (Idem, pp. 15-20), that is, the reduction of an object to a fundamental set of conditions for that object that derives from the way in which this object " $x$ " has been observed by a singular individual. Thus, the notion of type indicates the fundamental structures that an individual perceives for the possibility of the object labeled " $\mathrm{x}$ ", but the reality of such object is not only associated with its physicality in external reality (its objectivity), but also with the form in which this object is conceptualized in one's mind. ${ }^{5}$ This process is connected, then, to one's empirical experience of the object.

The question of the empirical experience of objects will motivate Weber to develop the notion of habit. Habits, for Weber, are the strategies that individuals develop in order to make sense of objects and to use objects that are available to these individuals. These habits create a familiar surrounding where objects can be apprehended and re-apprehended, where individuals can perceive the reproduction of patterns and learn the uses for the materials that surround them. This exercise of habituation is the core of what Weber calls observational understanding: typifications become denser, more complex, as individuals familiarize themselves with those objects that surround them (Idem, p. 24).
Though this process is common, in its structure, to all individuals in any given society (Idem, p. 27), the form in which individuals will appropriate meaning depends on, firstly, the peculiar history of each individual and the hermeneutic movement that such history will allow for that individual; secondly, the availability of objects in the surroundings of this individual.

Now, we have mentioned a hermeneutic movement in the process of appropriation of external reality (Berger and Luckman, 1967, p. 174). This hermeneutic movement, in Weber, constitutes a subjective social reality, and operates on the basis of a habituation, that is, a repetition and confirmation of former experiences. This densification of experiences allows individuals to conceptualize ideal types. Ideal types, on this first stage of meaning constitution, (and it is important to note that we are not yet on the level of social action), allow individuals to conceive of a normative conception for an object. This normative conception is not experienced by individuals in social life, ${ }^{6}$ it is not observed in social reality, it is, however, constructed with elements found in social reality and that individuals experience as particularly efficient.

In that sense, the construction of ideal types has an element of choice and preferences that is alien to the observational understanding of external reality (Weber, 1956, p. 20), and at the same time, it is dependent on the structures that are perceived and constructed by individuals as they conceive of their conceptualizations of external reality. Therefore, ideal types, at first, are the result of an internal deliberation of what the best possible conceptualization of an object is. Such process of typification implies that individuals will reach for former experiences and the particular successful elements of their former experiences regarding an object. Certainly, the "particular successful elements" here are nothing but the preferences of this individual regarding his/her former experience, and the choice of the elements of those experiences that he/she would like to see every time that he/she would encounter an object " $\mathrm{x}$ ". Thus, this person, in fact, is creating an ideal type.

Ideal types, at this stage, are the non-empirical conceptualizations of an external reality that indi- 
viduals develop - the best-perceived characteristics of a determined object - and will end up being intimately connected to the identity of an individual. ${ }^{7}$ The way in which these individuals are conceiving of ideals also indicates which preferences are particularly important for them: more so, they might indicate that certain aspects of the idealization will not be negotiable. That is, individuals will not voluntarily 'drop' their conceptualizations about ideal types and the fundamental structures of types in general when they enter social interaction.

Such tension will arise because individuals will use ideal types as the normative standard against which other types of the same sort will be judged. Certainly, one will be satisfied with less than ideal appearances of that type (Idem, p. 28), ${ }^{8}$ but the fundamental structure of the type is given within the syntax of the ideal type, and organized in accordance with it. In short: ideal types have a vertical relation to types, and a horizontal relation to the self. ${ }^{9}$ Weber wrote, "It is true that we regard as objectively valuable those innermost elements of the 'personality' those highest and most ultimate value-judgments which determine our conduct and give meaning and significance to our life" (Weber, 1949, p. 55).

Now, this begs the question of whether our previous understatement of ideal types as non-empirical is not bogus. After all, our value judgements certainly seem very empirical and hold both validity and normativity in a Weberian sense. However, on one hand, an ideal type has a psychological effect in the construction of a self (which is what we are calling the horizontal relation of ideal types to the idea of selfhood), but we will not to find ideal types in any material sense in Weber's sociology. We would like to stress here that ideal types are constructed, by Weber's own words, sharply and precisely. That is, they imply the structure that a determined type should have, and serve as an index of preferences that shape personal identity and orient attitudes towards the general value of a determined social experience. In that sense, idealities in Weber are an idealization of different isolated experiences into one idealized chimera.

Thus, in order to understand which values matter for isolated individuals, we must under- stand how that individual conceives of ideal types, that is, the chosen set of attributes that are regarded as most important for that individual, and which will be common in different ideal typifications.

To summarize, ideal types in Weber are not ever found in its ideal form in everyday life, but they are meaningful. Why so? They are meaningful because individuals have reflected upon the features of ideal types, and have reasons to judge every situation where two choices for types of a similar category are given according to an ideal type of that sort. Supposing as an example, an election. Individuals certainly have an ideal candidate in mind, that is, a candidate that has a set of characteristics. Assuming this scheme $[S, y, U, v, x, Z]$ where the capitalized characteristics would be the most important characteristics, and the non-capitalized would be desired characteristics in an ideal candidate - but not necessary conditions for the possibility of voting in that individual. Now, supposing that $[S, y, U, v, x, Z]$ are the characteristics of my ideal socialist candidate. We can still vote for the candidate that has characteristics $[S, o, U, t, r, A]$ rather than the candidate that has characteristics [F, b, K, g, x, A]. Hence, this could just mean that we prefer the candidate that fits a social-democratic profile rather than the candidate that fits a social-conservative profile. Also, it is important to note that both candidates in this situation will fit within a different type "Candidate", which has both an implication on an individual level (that is, what is a candidate for an election insofar an individual comprehend what it means to be a candidate) and on an institutional level (that is, the legal definition of who can be a candidate on an election, and what are the sufficient conditions to run in a state election).

An institutional level of social typification, as we will see, constitutes the third level of analysis for Weber. ${ }^{10}$ However, the second level is social action "proper" and will shape the understanding of the institutional level in multiple ways. But, for now, we are only establishing a meaning-complex for objects that surround individuals. This means that the observational understanding of objective reality shapes a social reality for a subject, and allows objects to acquire meaning for an individual. Thus, shaping the uniqueness of a first person perspec- 
tive in Weber, i.e., individuals historicize and make sense of objects privately, and also have a constituted idea of what objects and values are like when they enter social relations.

However, as we have anticipated, this observational understanding will take formal precedence to the other forms of shaping social reality, and, in many ways, will conduct the further aspects of the social action. However, Weber would not share what Rawls (Pontin, 2013) would later develop as the idea of an original position wherein individuals are shaping the institutional framework that they will further enjoy. There is no ex-nihil moment when parts constitute institutional reality or choose preferences. Rather, individuals are born into certain constituted institutional frameworks and are somehow affected by such framework. They also incorporate elements of a shared historical construction, such as national identity, religious voluntarism, and family background. In that sense, the first person perspective integrates heavy elements of social interaction and institutional placement (O’Neil, 1972). In the next section, we will show how the second level of social action, where one enters interaction and interpretation of different social meanings, adds some density to the first level of action we just described, and will allow us to comprehend how different levels of conceptualization, though formally precedent to each other, are collapsed in the social life.

\section{Social action: from the familiar onto the strange}

Heretofore, we have described the tension between objective and subjective social reality in Weber. Objective social reality constitutes those elements that are available for an individual to observe and integrate into his/her own understanding of values and types. The subjective social reality is the meanings that are associated with objects in the world, as they are understood by a peculiar individual with a determined view of a society.

Weber had limited his analysis of ideal types to a subject-object relation, from this; we would have reason to find his description to be rather thin. However, the subject-object relation only gives us a formal basis for our understanding of what an ideal type is and how it is constituted. The concept of social action becomes thicker as individuals enter social interaction.

Now, an interesting feature of the social interaction in Weber is that it somewhat presupposes meaning constitution, but it presupposes on different levels, depending on the sort of interaction we are dealing with. We will follow the insight of Berger and Luckmann in The social construction of reality in this section, aiming to draw a distinction between primary and secondary socialization (Luckman and Berger, 1967, pp. 129-147), and present the different sort of orientation that we find in social interaction in these levels of analysis.

Primary socialization will include all immediate surroundings wherein a subject is inserted. What kind of nuclear family was this individual born into? What kind of early education did /she experience? Evidently, primary socialization can also be understood in negative terms, for example, lack of education and stimuli, exposition to disease, extreme poverty and so on. Now, primary socialization also works as a sort of objective social reality. It participates giving to an individual a set of possibilities for his/her processes of signification, a set of early choices. One's form of orientation towards meaning, in that sense, is motivated by primary socialization and it can constitute dense habits of the meaning constitution that will lead, as we will see, to consequences in the future forms of socialization.

First of all, primary socialization introduces a circle of familiarity, a circle of individuals with whom you share a set of experiences. This means that primary socialization introduces a secured group in which you can trust, at least, some agreement insofar the "grammar" of associations to objects and values are concerned. These individuals share some of their ideals and are in agreement with the structure of most of the objects that surround them. There is an order to processes of signification, and this order is shared by individuals who share primary socialization.

Our relationship towards these individuals, then, presupposes that we know what we are talking about when we enter social relation - that is, that we share the same sort of orientation towards 
meaning, that we take the same fundamental features of social reality as absolute, in short, that we share an identity.

Secondary socialization is the introduction of strange elements into our primary processes of signification and identity. Primary socialization constitutes an early "stock of knowledge", a set of meaning constitutions and a group of individuals with whom we share this stock of knowledge. As long as we remain in primary socialization, the sort of conflict that exists in terms of meaning constitution and the structure of concepts and values is given within a common grammar for value-like and object-like statements. Not only do we share a common idiom with our peers, we share a set of possible conceptualizations.

The relationship with our peers introduces a common lexicon for agreements and disagreements, a common grammar of social relation. ${ }^{11}$ Nevertheless, the figure of the stranger brings a further difficulty to the process of the meaning constitution. The introduction of the stranger is the emergence of an individual (or group) that does not share our "stock of knowledge”. What secondary socialization introduces, then, are new possibilities of meaning constitution. However, the way in which one reacts to this secondary level is deeply connected to the sort of primary socialization one was subjected to. The key point, however, is that what we understand as an action oriented towards meaning might be understood as an instinctive behavior by our interlocutor.

Though granted that there is an encounter, there is an ignition to a process of secondary socialization, and this process will irreversibly change the form in which meaning has been constituted to us, it will change the way in which we conceive of social action. As it happened the case with primary socialization, secondary socialization can also acquire negative connotations, that is, it can constitute meaning in negative terms - that which we believe is that which that other group does not believe in, that which we value is that which other groups do not value.

More decisively to Weber, secondary socialization introduces the issue of voluntarism and conflict in radical terms (Weber, 1956, pp. 52-53). As we have suggested before, conflict in primary socialization is given only from the standpoint of a shared set of meanings, a shared set of possibilities. In secondary socialization, conflict is radical. As one can voluntarily drop some of one's own assertions about meaning in order to enter a relationship with a stranger, one can also try to find a common ground, and even establish a new grammar for social relations that include some of the assertions of the stranger. ${ }^{12}$ This voluntaristic effort was not possible - after all, we hardly, and perhaps unfortunately, do not choose our own family or country in which we are born - in primary socialization.

Now this different sort of meaning constitutions have been brought into play, we can choose to incorporate these elements into our own "stock of knowledge", consequently increasing the scope of our set of possible meaning constitutions, and perhaps, reevaluating which values matter and what are the absolutes that constitute our personal identity.

Institutions will start to take a stronger shape as communities become larger and asymmetrical. As it was the case with Hobbes, institutions arise in Weber to integrate a common grammar for different sorts of socialization and meaning constitution. However, Weber stresses the elements of loss and nostalgia that will mark this processes, as certain features of early socialization are dropped in order for the prevalence of a higher institutional order of values and absolutes. Interestingly, this higher institutional order, as far as Weber is concerned, is as open as the former primary socializations that now form a State allowed it to be. In this sense, closed States might indicate closed forms of primary socialization, whereas open states indicate open forms of primary socialization. The institutional level reacts to the early communitarian organization. The institutional order is a mirror-image of the social order and imaginary that gave rise to the institutional order, it is a reflex of a history of the meaning constitution and value orientation.

We hope it is clear by now that we are suggesting two sorts of primary socialization in Weber. First, we are indicating that family and a small community that surround the family (neighbors, or a village) create an objective social reality that informs the formation of an early "stock of knowledge" for an individual. In time, this community 
grows in size and scope and will become something similar to a State. The State, then, creates its own elements of objectivity, its own set of norms and its order - and takes the place of the nuclear family, in many aspects.

\section{Order, social organization, and power}

Observing Weber's (2013) classic study, The protestant ethics and the spirit of capitalism, we will notice a description of these levels of socialization and institutionalization in the North-American context. We will note, for example, that religious elements particular to the primary socialization of Protestants that came to the USA were prevalent in the development of a work ethic and in the organization of a bureaucratic order. We will also perceive that primary socialization implied a sort of standard of the community for the larger, institutional, order.

In fact, it seems that one of the main roles of the State in Weber is to increase the scope of primary socialization (Luckman and Berger, 1966, pp. 129-147). If in small communities the objective social reality was given by a stock of knowledge represented by family and religious background, the state aims to expose individuals to a larger stack of knowledge as "primary", both in order to make the possible framework of social relations complex, but also in the hope of decreasing the likelihood of internal conflict.

The notion of founding acts (The Mayflower for North Americans, the Bolivarian Revolution for Central Americans, the Minas Gerais Conspiracy and the Emancipation of Slavery for Brazilians), takes the place of the heritage as an organizing principle of common identity. They orient a population towards a common set of absolutes represented in a founding act. Surely, these references are appropriated and claimed for political gain and in different contexts (after all, the Mayflower used by Glenn Beck to claim the originality of a certain narrative of the American myth is different from the Mayflower as seen from the standpoint of $\mathrm{Na}$ tive-American populations). It is also interesting to note that revolutionary movements in society usually focus on the instauration of a new founding act (the fall of the Bastille for modern France, the Red Book for communist China, and the fall of the Berlin wall for unified Germany). All these moments are implementing a common social imaginary and a common set of principles that guide, within a state, primary socialization. If we observe the totalitarian societies or states moving a more authoritarian model, national sentiment can even override family tradition, heritage and religion as the guiding principle of all identity formation (considering North Korea, Nazi Germany, and Peronism, we can note that the leader in these circumstances is a "Great Father").

Still, the organization of social order in the State is the result of elements of primary socialization and secondary socialization of individuals and relationships between individuals that led to the development of an institutional order that mitigates social conflict and relationships.

There is no State in Weber without the notion of monopoly of the legitimate use of force (Weber, 1956, pp. 232, 314), and once again Weber seems to validate, from the standpoint of a fully developed capitalistic society, the terms thought by Hobbes in an incipient capitalism, i.e., a constituted institutional order presupposes that the State is in charge of the legitimate use of violence and has some sort of control over economic and normative order. This is another interesting difference between institutionally and non-institutionally based orders.

Consider, for example, pre-Westphalian societies (Idem, pp. 255-262). It is true that there were some sorts of State, particularly in European societies, in those situations. Still, it would be unusual for most individuals to feel any impact of the institutional order in their upbringing. The central authority was the leader of the nuclear family and the religious authority. A main shift in the European scenario was represented here by the Protestant Revolution - which was, not forget, one of the main forces in the popularization of literacy, a turning point in Western society, and, for Weber, a clear mark in the development of "institutional reason" (Idem, pp. 319-323).

Nevertheless, up to the Westphalian division of Europe, most communities were decentralized and 
did not share a written normative ordering. Rather, most communities relied on the costume as a standard for judging anomic behavior, and deterrence groups were not organized by the State, but usually, militias made out of voluntaries or mercenaries that would take the maintenance of order into their own hands.

With the urbanization of Europe and the religious wars that plagued the continent throughout three hundred years, a more homogeneous form of organization for the larger community became necessary. It was no longer possible to rely on the openness of different sorts of primary socialization in families and small communities, and hope that conflict could be averted. The State rises, as Michel Foucault would put it, in defense of society. It arises to reinforce a homogeneous form of social relation and identity and to pacify forms of social typification.

At this moment, we can summarize our interpretation of the process of identity formation in Weber as folded in three different stages.

First, we have a process of the meaning constitution that is regarded as a first person perspective of objective social reality. Such perspective takes the shape of a subjective social reality that informs an order of reference-meaning relations to a self, introducing the first ranking of social preferences in types which are had in context to what sort of objects are available. It also constitutes what is "acting towards meaning" for an individual. In this stage of identity formation, ideal types and subjectivity are understood in relation to objects in the world.

Secondly, we have a transformation of the process of the meaning constitution into a process of social action. This process is divided into social action, in terms of primary socialization, and secondary socialization. In primary socialization, we are exposed to non-voluntarist aspects of social relations. Family, social, and geographic placement et cetera, constrain the possibilities of the subjective constitution of meaning and activity. They also constrain the sort of habits and typifications that individuals can experiment with. In that sense, the diversity of meaning appropriations of an individual has a heavy element of destiny, at least, up to the point that this individual encounters someone who has been subject to a different sort of primary socialization and therefore has a different set of reference-meanings constituted. This might operate in individuals as a negative or positive experience, as it transforms some of the former ways in which identity had been constituted, and reconfigures valueorientations and absolutes, or re-enforces previous beliefs, and operate negatively. Here, the closeness or openness to the stranger is somewhat dependent on what sort of objectivity the individual was exposed to in primary socialization.

Social interaction is labeled then in terms of relations and conflict. Both are constituted differently in primary and secondary stages of socialization. In primary socialization, conflict and relations among individuals presuppose a shared grammar for value expressions and a shared conceptualization of absolutes and ideas. Individuals in primary socialization actually share what Habermas calls "communicative reason", that is, they actually agree upon meaning-object relations and the set of possible meaning-object constitutions that are available. However, social relation and conflict in secondary socialization do not presuppose a shared core of meaning-constitutions. Here, the relation can be of reconstitution of "familiarity", wherein the emergence of new sorts of constitutions actually enriches and change the scope of values in an individual (who can, ironically, now enter conflict with his/her primary socialization), or, it can be constituted as a conflict. Weber traces the question of the religious wars, for example, to this sort of struggle between primary and secondary socializations. As Hobbes before him, Weber will connect the origin of the State to the necessity to manage the processes of exchanging of values (both economic and social) between different individuals (or other social organisms, such as groups and institutions).

Third, we have the State as the institutional ordering of a common primary socialization. The State reorders the possible conceptualizations of values that can be held publicly, that is, in open social relations. In that sense, it takes the place of private primary socialization insofar social relations are concerned. Does that mean that individuals will cease to be influenced by their family or by their immediate surroundings? Of course not. However, 
it does mean that individuals will now add another historical element to their process of identity building. The introduction of state schools, police, and sanitation are, in fact, a way to commonly manage individuals that are subject to different sorts of primary socialization in their families. It levels the playfield in a larger society, and it creates a homogeneous standard of values and types. Now, Weber is well aware that there will be different sorts of social ordering, creating different sorts of States. Hence, we will be subject to the conflict between different notions of ideals and values that have been constructed within different states.

\section{Social action and meaning in context}

Previously, we wrote about the "space of similitude" in the Hobbes' description of social reality. Now, we would like to recall that in the discussion of the reason and behavior in Weber's sociology.

Heretofore, we have discussed the different levels of social interaction and how these social interactions pave the way for a dense understanding of the process of identity formation. We hope it has become clear by now that identity, in Weber, trusts a sort of establishment of an internal grammar for associations regarding the external world that, in time, becomes a common grammar for interactions about the external world. In this sense, the "I" of a first person perspective becomes intimately related to a "we" of common perceptions. This establishes an order for the possible sets of meaning-references, thus setting the stage for both a set of individual values and common absolutes.

We have already anticipated these two levels of rational orientation, but before proceeding to the next section, we need to clarify what constitutes rational and irrational behavior in Weber. First of all, it needs to be clear that were taking certain liberties with the text here, Weber himself never speaks of irrationality or even behavior, but we do consider that his understanding of meaning and action in the context should allow us to presume that irrationality or behavior also operate in context.

By that, we mean that the set of possible meaning-references that establish an order for an individual also put in context the possible meaning-references that do not fit that given order. First, they might not fit the discrete ends of a certain type of discourse, for example, the kind of objectivity, which is established as the rational discourse within the scientific community or the justice system. We are dealing with the construction of objectivity within the construction of social reality: different sectors of society, then, will create their own "objectivities", be it related to orders constituted by religion, labor or the State. Within different societies, different institutional constructions might play more determinant roles, within modern societies the State takes the center stage as the ordering force which will establish an "objectivity for objectivities", that is, it will frame the common grammar in which even individual "discrete" ends will operate.

Weber's geniality is to point that without an understanding of how these processes take place in different society there is hardly any chance that we will make sense of how preferences and choices come to be the case for individuals. For example, we need to understand that the isolated individual making choices at an isolated moment in time is a fiction. There is no way that this individual is making choices outside a historical framework that constrains and shapes the sort of choice he/she is going to make. There is space, within this historical framework, for some sort of mobility, but it is also decisive to note that certain sorts of socialization will implicate less possibility for mobility and change - and hence the importance of secondary socialization for the possibility of social change. For example, the dynamics of immigration might help us understand the processes of social change in the 21st Century. Certainly, immigration is not new to North America, but as the composition of the American population starts to change radically and the white, Anglo-Saxon, individuals that shared the Puritan myth of the Mayflower become the minority, a sense of loss and nostalgia starts to be more prevalent. In that sense, can we really fault individuals that hold an anachronistic sense of identity? A Weberian analysis would then suggest that anachronism must be understood in context, it must be seen as a perception of an ideal, or of a value, that holds only an apparent relation to the normative 
establishment of that value in social order. There is a disorder between the absolute as perceived by an individual, or a group, and the absolute as given in the social order as a whole.

In that sense, there is a static element which gives an order to the processes of meaning-constitution in Weber, this element is the normative order in which an individual or group is making choices. That is, if there is a disorder, a disturbance, in the establishment of a meaning complex that does not "fit" the current set of absolutes, this element of disorder will thus be considered an "irrational" choice, a behavior that does not agree with a present order of possible significations. Weber would argue that it does not "aim" at a common grammar that rules a discrete system of individual ends in a society and is thus "irrational".

Weber relies deeply on the importance of reason and objectivity for social action, both of these are understood as contextually based notions, which rely on a sort of social construction of what is objective and what is reasonable. Even if we accept the Weber's distinction between absolute and instrumental understanding, the social construction of that which is understood as absolute remains. It seems to us that this should indicate that Weber would not accept a notion of structure for social reality outside the frame of a particular society. He could very well accept that certain forms of objectivity could be more or less defensible than others, but we do not consider one could point at a sort of independent necessity of certain forms of understanding in Weber, that is, that certain forms of asserting the objectivity of external reality are necessarily better than others. As a matter of fact, external reality, in Weber, seems to be equal to an external reality "for me", that is, it is always already in relation to individual appropriation of what is "external".

Considering, for instance, the constitution of a preference. If we take Weber seriously, we can consider preferences in two modes, first, in an ideal mode, in which a preference reflects an absolute for that actor, in the last section we called that an "ideal type". The rational orientation towards this kind of type would be absolute in the sense that given all the information that the actor has about that object, this would be what he/she would consider the most preferable possible state for that given case. Again, these sorts of preferences, and we cannot stress this enough, are not empirical in the Weberian notion of social action. They are rather idealizations of pieces of experiences that build up an ideal. Second, we have an "instrumental" or "pragmatic" mode in which an actor constitutes preferences, in which he/ she bargains the set of a preference which is constituted as an ideal and chooses whichever set available is closer to the one he/she had set as absolute. In both instances, we are dealing with, firstly, representations of preferences, which operate on a rational basis: actors really are thinking these elements through in society. In Weber (1956, p. 85), we do not behave towards preferences; we rather rationally act towards constituting something as preferable to something else. Second, we are dealing with, at least in the moment in which we act, a completely constituted set. In the moment in which we choose the temporal and hermeneutic process leading to that decision is over, and we have the constitution of the act. Interestingly, it seems that in Weber the moment of representation of the ideal type as ideal, or the moment in which we define a type as acceptable within the parameters of instrumental reason, is the very moment of choice.

Such level of analysis is more complex than a mere reproduction of a heritage. It attempts to reduce some elements of heritage into an organized system of references, which is further established as a model of any analysis that could be labeled "scientific". In that sense, the stock of meaning-complexes that ground a heritage is 'purified' into a scientific meaning-complex. The problem with this mode of proceeding is that it super-imposes a model of analysis of the lifeworld, one way of understanding and appropriating meaning, as the norm for all sorts of analysis.

It is interesting to note that while Weber, on the one hand, opens the door for a phenomenological and hermeneutic analysis of social action with his historicist understanding of the process of types and individual, and social identity, his methodological heritage in Hobbes' methodological individualism seems to lock him out of the less rationalized and controlled aspects of social life. This seems to be the point that Schutz tries to stress, attempting to 
recast Weber under a more phenomenological and less rationalist perspective. Schutz will stress that the dynamic nature of identity constitution also reconstitutes the environment, or the social-organism, where actors are situated, so the social surroundings that once affected a social actor is now affected by one's acts. This temporal dialectic of being-affected by social reality and constructing new conceptions onto social reality characterizes the social construction of the lifeworld. Such process is underdeveloped by Weber (Schutz, 1932, pp. 9-27).

Schutz appropriates the entire lexicon of Weberian sociology, infiltrating some elements of phenomenology for two effects. First, Schutz would like to broaden the scope of Weber's sociology, by reframing the question of the "terms" in which we argue the structure of social reality. Schutz, in this sense, anticipates a problem in Habermas' normative view of society: the structure of social reality cannot be just a matter of an intersubjective agreement of what the terms used to describe external objects should be (Idem, p. 9). Nonetheless, the question of sense and meaning is left unsolved in classical sociology precisely because it is taken for granted as a matter of raw epistemic collection of "world views". Secondly, Schutz interprets the Weberian analysis of types with a structural phenomenology, which in turn allows him to disclose the structure of the social world as a structure of intelligible intentional meaning. Intentionality, of course, is the key point here: Weber speaks of "intended meaning" in an empirical sense, as in "what was meant" in a sentence uttered by a social actor. In Schutz, intentional meaning refers to the structure of intentionality, trying to demonstrate that the social behavior of an actor is already given in a context, and that the "individual" actor is also inserted in a social space. In that sense, Schutz dislocates the solipsistic development of solitary constitution of meaning in Weber, introducing a field wherein a social phenomenology would operate.

This dislocation operates on Schmutz's understanding of temporality and how it shapes behavior and reason, that is, how time-consciousness allows us to speak of the constitution of personality differently. Identity formation, in Weber, presupposes the existence of a primary form of socialization that informs and binds individual conceptions. Socialization, then, takes place within a certain social structure, and the process of formation of identity is immediately informed by social reality - by the surroundings of a social actor. This first movement is further made more complex in secondary form of socialization, but in this context, the individual already has something like a "formed" personal identity. Thus, personal identity in Weber is dependent on the immediate aspect of socialization, on the form of early socialization of an individual. Besides, this dependency does not provide social actors with a static form of identity; further socialization might render aspects of primary socialization undesirable, or put them under a different light.

Weber presupposes that meaning is always rationally constituted, that it can be described in a detailed analysis of a conscious individual that is in full control of which elements of his/her primordial world of experiences are affecting his/her experiences. The individual's judgment of something as meaningful is perfectly coherent within a system of references, and behavioral factors do not enter play as "meaningful".

We do not consider it is controversial at all to claim that social action in Weber is a matter of ordering a previous stock of shared and individual knowledge and expressing this knowledge as a preference, as something that one values. In that sense, when we affirm that we choose $\mathrm{x}$ rather than $\mathrm{y}$, we are expressing a historically constituted scheme of representations which is consciously chosen by us. We are expressing an ordered and rational interest. In some scenarios, if we are dealing with goods or values that are of importance to what we consider to be the core of ourselves, then we will attribute a static value to that good or value, that appears to me as absolute. In both cases, our preference is ordered, rational and fully under our control.

\section{Conclusion}

Weber had to stress the prevalence of meaning in his study of social relations. This is particularly clear once we understand his methodology: social actors operate in society in a diverse fashion, but 
sociology can only be occupied with the aspects of this operation that can be circumscribed to rational expression of values and preferences by this individual. Weber trusts that society is ultimately formed by rationally oriented individuals who pursue their goals in a conscious and ordered fashion. In that sense, when we act in society we act with the meaning of our act fully constituted, at least from our point of view, and we expect our interlocutor to be able also to understand the meaning of our action. Accidents in this process, as far as Weber is concerned, are either a result of primary aspects of socialization that were not shared, or of instrumental interpretation of social acts for aggressive motivations. Still, the orientation of the action is towards meaning. We "mean to say" something when we act in society, we want to communicate an interest and be understood in this interest.

This process of orientation towards meaning, and the social creation of a stock of knowledge is a reflex of the effect that the Hobbes' account of society had in Weber. However, this leaves as a side effect a nominalist attitude in Weber's account of the construction of social reality. Nota bene, this is not to say that Weber approaches the problem of representation from a platonic, fully ideal, point of view. Still, the Weberian attitude towards the concepts and types, and the sort of social reality that these types produce will generate a stratification of reality, which turns the process of resignification and historical reevaluation of experience into a history of grammatical reconsideration of types.

Ultimately, Weber is not able to recognize the disordered aspects of the meaning constitution and, consequently, the way in which social identity is shaped by contingent, and sometimes not-meaning-like, aspects of everyday life. However, perhaps the fact that we are able to identify this limitation is one of the most impressive aspects of Weber's influence in social theory.

Without a Weber's seminal analysis of the production of knowledge and identity within society, we would not be able to point at the limits of the hermeneutic turn in sociology. Even as we indicate at the insufficiencies of the representational paradigm adopted by Weber, we do so from the standpoint of a system of representations and a limited stock of knowledge. Considering that Weber was not able to point at the limits of social action as rational and meaning-oriented, we are analyzing the framework of social sciences and knowledge to which Max Weber himself was bound, and, hence, we reaffirm the situated analysis of the production of knowledge (social or otherwise), that Weber introduced in Economy in society.

In this sense, even as we point at the limits of Weber's account of meaning and order in society, as re-affirm his own paradigmatic shift, as we do so from the standpoint of our own socializations and aware that historicity is indeed the start point of every analysis of social behavior.

\section{Notes}

1 [ $\mathrm{t}$ ]he most noble and profitable invention of all other, was that of SPEECH, consisting of names or appellations, and their connection; whereby men register their thoughts; recall them when they are past; and also declare them one to another for mutual utility and conversation; without which, there had been amongst men, neither commonwealth, nor society, nor contract, nor peace, no more than amongst lions, bears and wolves" (Hobbes, 2005).

2 Because this imagining is still internal and mechanic, both men and dogs are capable of imagining and understanding in this mimetic level (Hobbes, 2005, p. 556). It is in this sense that imagination is only a decay of sense (Idem, pp. 554-555), not yet a discursive reproduction of sense.

3 Weber calls this "direct observational understanding" (Weber, 1956, p. 8).

4 This process of conceptualization allows us to speak of "intended meaning" (Weber, 1956, p. 9).

5 Thus, social action becomes "rational orientation to a system of discrete individual ends" (zweckrational) (Weber, 1956, p. 24). We will return to the question of rationality in Weber later in this section.

6 "The more sharply and precisely the ideal type has been constructed, thus the more abstract and unrealistic in this sense it is" (Weber, 1956, p. 21).

7 This value then takes the shape of an absolute value and becomes, as far as the individual is concerned, an end in itself. Weber calls this a rational orientation towards an absolute value (Wertrationalität) (Weber, 1956, p. 24). 
8 Though individuals generally would prefer their absolute values, to act towards these values in every circumstance could prove irrational, or just impossible.

9 We are using these terms without much philosophical weight right now. At this point, we would like to argue that a vertical relation means that something is regarded in a "higher" order to something else. Thus, if ideal types have a vertical relation to types, I mean that they are a somewhat ideally constituted notion of a type, which regulates the way in which other types of the same sort are expected to appear. Conversely, affirming that a self has a horizontal relation to ideal types, means that the constitution of personality is in direct relation to that which we consider "ideal" - it is therefore in the same level of analysis.

10 Luckmann and Berger provide a very elegant description of such level under the rubric of "legitimation" in The social construction of reality: a treatise in the sociology of knowledge (Luckmann and Berger, 1967, pp. 92-128).

11 In Weber, this "common grammar" of social relations is based on shared tradition, faith and enactment. These modes of primary social relation set the stage for the main actors in social life: family, religion and the State.

12 See "Open and Closed Relationships" in Weber (1956, pp. 43-46). Also "Change through inspiration and empathy”, in Weber (1956, pp. 321-323).

\section{BIBLIOGRAPHY}

ARISTOTLE. (1998), Politics. Cambridge, Hackett Publishing Company.

BERGER, P. \& LUCKMANN, T. (1966), The social construction of reality: a treatise in the sociology of knowledge. New York, Anchor Press.

BERLIN, Isaiah. (1984), "Two concepts of liberty", in M. J. Sandel (ed.), Liberalism and its critics, New York, New York University Press.

GAY, Peter. (1966), Enlighten, the rise of modern paganism. New York, Vintage.

HOBBES, Thomas. (2005), "Leviathan or the matter, form and power of a common wealth ecclesiastical and civil", in Michael Morgan (ed.), Classics of moral and political theory, 4. ed., Cambridge, Hackett Publishing Company.
MILL, John Stuart. (2008), Principles of political economy. New York, Oxford University Press.

O’NEILL, John. (1972), “Can phenomenology be critical?”, in T. Luckmann (ed.), Phenomenology and sociology, New York, Penguin Books.

PONTIN, Fabrício. (2013), "Political economy and the roots of Rawls' original position". Dois Pontos, 10 (1): 177-194.

RAWLS, John. (2007), Lectures on the history of political philosophy. Cambridge, Harvard University Press.

SCHUTZ, Alfred. (1932), The phenomenology of the social world. Chicago, Northwestern University Press.

WEBER, Max. (1949), The methodology of the social sciences. Glencoe, The Free Press. . (1956), Economy and society: an outline of interpretive sociology. Berkeley, University of California Press. . (2003), The protestant ethics and the spirit of capitalism. New York, Dover Publications. 


\section{O HISTORICISMO DE WEBER COMO UM CAMINHO PARA A FENOMENOLOGIA}

\author{
Fabricio Pontin e Tatiana Vargas Maia
}

Palavras-chave: Historicidade; Conhecimento; Representaçáo; Ordem.

A descrição de Weber sobre identidade e sociedade permanece como uma necessidade paradigmática e modela nossa compreensão de como os indivíduos vêm a ter suas preferências e de como desenvolvem um senso de si próprios nas sociedades modernas. No entanto, apesar de toda sua importância paradigmática, a posição de Weber a respeito da formação do eu e da identidade possui um ponto cego em sua noção de representação. É de nosso entendimento que a centralidade da noção de representaçáo, na compreensáo de Weber sobre a açáo social e o eu, o coloca em uma posiçáo nominalista. Portanto, embora o conhecimento seja produzido localmente, a vida social busca e é, também, limitada pela produção de conhecimento. Isso deixa Weber incapaz de lidar com o problema da desordem na vida social sem recorrer a uma interpretação da desordem como irracionalidade, o que, como propomos, não é mais aceitável.

\section{WEBER'S HISTORICISM AS A WAY INTO PHENOMENOLOGY}

Fabricio Pontin e Tatiana Vargas Maia

Keywords: Historicity; Knowledge; Representation; Order.

Weber's account of identity and society remains a paradigmatic necessity and shapes our understanding of how individuals get to have preferences and form a sense of self in modern societies. However, for all its paradigmatic importance, Weber's account of the formation of self and identity has a blind spot in the notion of representation. In our perspective, the centrality of the notion of representation for Weber's comprehension of social action and selfhood leaves him in a nominalistic position. Thus, though knowledge is produced locally, social life aims at and is limited by the production of knowledge. This issue leaves Weber unable to deal with the problem of disorder in social life without resorting to an interpretation of disorder as irrationality, which, we hold, is no longer acceptable.

\section{L'HISTORICISME DE WEBER EN GUISE EN PHÉNOMÉNOLOGIE}

Mots-clés: Historicité; Savoir; Représentation; Ordre.

La description de Weber sur l'identité et la société demeure un besoin paradigmatique. Elle sculpte notre compréhension sur la définition des préférences des individus et de la façon dont ils développent une conscience d'eux-mêmes dans les sociétés modernes. Cependant, malgré toute son importance paradigmatique, le point de vue de Weber au sujet de la formation de l'individu et de son identité possède un point aveugle dans son idée de représentation. Nous comprenons que la centralité de la notion de représentation, selon la compréhension de Weber à propos de l'action sociale et de l'individu, le place dans une position nominaliste. Ainsi, malgré le savoir produit localement, la vie sociale est objective et limitée par la production du savoir. Cela rend Weber incapable de faire face au problème du désordre dans la vie sociale sans recourir à une interprétation du désordre en tant qu'irrationalité ce qui, comme nous le proposons, n'est plus acceptable. 